\title{
(A) com \\ OPEN ACCESS \\ Diagnostic dilemma: think about anterior cutaneous nerve entrapment syndrome (ACNES) in patients with atypical abdominal pain and Crohn's disease
}

\author{
Kenneth Lam, Carolyn Vasey
}

Gold Coast University Hospital, Southport, Queensland, Australia

Correspondence to Dr. Kenneth Lam, kennlam.93@gmail.com

Accepted 14 March 2018

\section{Check for updates}

(c) BMJ Publishing Group Limited 2018. Re-use permitted under CC BY-NC. No commercial re-use. See rights and permissions. Published by BMJ.

To cite: Lam K, Vasey C. BMJ Case Rep 2018:2018:e224041. doi:10.1136/bcr-2017224041

\section{SUMMARY}

Chronic abdominal pain can be a difficult diagnostic dilemma. Anterior cutaneousnerve entrapment syndrome (ACNES) is a potential differential diagnosis that should be considered because treatment is both easy and effective. We describe the case of a 51 -yearold man presenting with 7 months of right lower quadrant abdominal pain on the background of known Crohn's disease. A circumspect surgical approach and multidisciplinary input was key to making the diagnosis of a nerve entrapment syndrome.

\section{BACKGROUND}

Nearly 1 in 50 patients who present to the emergency department with abdominal pain have anterior cutaneous nerve entrapment syndrome (ACNES). ${ }^{1}$ Diagnosis is often difficult owing to the many other potential causes for abdominal pain. ${ }^{2}$ The confounding factor in this case was the history of Crohn's disease.

\section{CASE PRESENTATION}

A 51-year-old man presented to emergency for investigation and management of right lower quadrant abdominal pain that had persisted for 7 months. The pain was sharp and aggravated by movement. The patient also reported increased stool frequency at the time of presentation.

The patient had a history of Crohn's terminal ileitis which had been managed medically.

There were multiple factors that supported the diagnosis of Crohn's disease as the cause of pain in this patient. First, this patient had biopsy proven Crohn's ileitis managed on azathioprine. Second, the right lower quadrant pain was initially associated with increased stool frequency. Third, imaging studies and colonoscopy findings suggested a possible flare of Crohn's disease. CT (figure 1) studies revealed subtle fatty changes within the wall of the terminal ileum and colonoscopy findings found two discrete 5 to $6 \mathrm{~mm}$ ulcers just beyond the ileocaecal valve in the distal ileum.

However, other investigations did not suggest a Crohn's flare-up. Serial faecal calprotectin results between 10 and $27.8 \mu \mathrm{g} / \mathrm{L}$ were low and did not reflect active luminal disease. Furthermore, a white cell count of $8.3 \times 10^{9} / \mathrm{L}$ and a $\mathrm{C}$ reactive protein of $<2.0 \mathrm{mg} / \mathrm{L}$ did not suggest any inflammatory process. Ultimately, it was the objectivity of a diagnostic laparoscopy that demonstrated a normal terminal ileum that lead the treating team to consider alternative diagnoses.

Moving away from the diagnosis of a Crohn's flare-up, the patient's history was revisited. The 51-year-old man reported sharp pain and rightsided specific point tenderness at the level of the umbilicus when completing movements like getting out of bed or climbing up into a vehicle. The aggravating mechanism of action described by the patient represented tensed abdominal musculature. This history suggested the cause of the patient's symptoms to be somatic in nature rather than visceral. In consult with the anaesthetic team, a diagnosis of ACNES was then explored. Reproducible abdominal pain against a tensed abdominal wall revealed a positive Carnett's sign. ${ }^{3}$ A successful rectus sheath nerve block with $1 \%$ lignocaine and $0.5 \%$ ropivacaine confirmed the diagnosis of a cutaneous nerve entrapment syndrome.

\section{TREATMENT}

A rectus sheath nerve block was completed by our anaesthetic pain service. Lignocaine of $1 \%$ was injected into the skin for local anaesthetic. Under ultrasound guidance, $25 \mathrm{~mL}$ of $1 \%$ lignocaine and $0.5 \%$ ropivacaine was then injected into the right rectus sheath.

\section{OUTCOME AND FOLLOW-UP}

Follow-up occurred 3 weeks post nerve block. The nerve block provided $95 \%$ pain relief for 72 hours. Over the next 3 weeks, pain in the right lower quadrant started to return, but not to the same extent as before the nerve block. If pain persists, the patient will be referred to a chronic pain specialist for a repeat nerve block or permanent surgical neurolysis.

\section{DISCUSSION}

Chronic abdominal pain can be a difficult diagnostic dilemma. The difficulty of attributing pain from visceral and somatic causes often requires considered diagnostic testing before the cause is established. ${ }^{4}$

Van Assen et al found that approximately 2\% of patients who present to emergency with acute abdominal pain have ACNES. ${ }^{1}$ Women appear to be more commonly affected then men, with a peak incidence between 30 and 50 years old. ${ }^{25}$ 


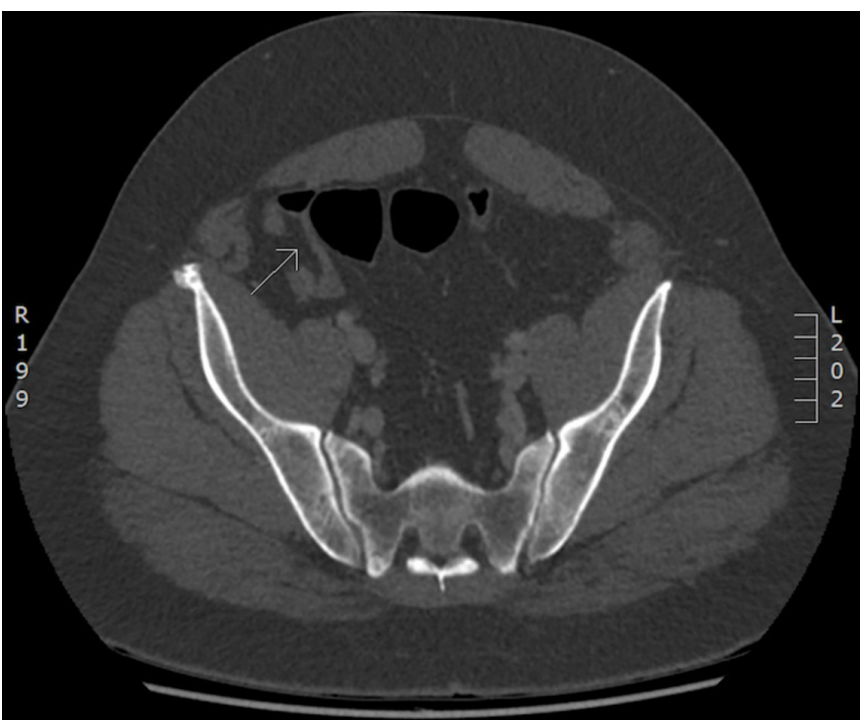

Figure $1 \mathrm{CT}$-arrow points to subtle fatty change within the wall of the terminal ileum, which can be a feature of chronic inflammation.

The anatomy and pathophysiology of ACNES is described by Applegate and Koop. ${ }^{3}$ The cutaneous branches of the thoracoabdominal nerves from T7 to T12 supply somatic sensation to the abdominal wall. At the lateral edge of the rectus abdominus muscle, these cutaneous nerves travel through a fibrous ring called the rectus channel. The fibrous ring provides a smooth surface for the nerve bundle to travel from the inner to the outer part of the abdominal wall. Ischaemia or irritation of these nerves can lead to pain. Applegate describes three key mechanisms. ${ }^{6}$ First, increased intra-abdominal pressure can herniate the neurovascular bundle through the rectus sheath causing the bundle to bunch up against the fibrous ring. Second, stretching the neurovascular bundle through the rectus sheath can cause the nerves to swell and compress blood supply causing relative neural ischaemia. Third, the nerves can be affected by scar tissue. Lindsetmo and Stulberg suggest that abdominal surgery, surgical scars, acute physical activity, obesity and pregnancy are all possible risk factors for ACNES. ${ }^{2}$

Owing to its rarity and difficulty in diagnosis, ACNES often presents as a chronic pain problem with $30 \%$ to $35 \%$ of patients reporting pain starting more than 1 year before the initial presentation. ${ }^{3}$ Classically, the pain is described as sharp or burning. Movements that tense the abdominal wall-like lifting can aggravate the pain. Importantly, the location of abdominal pain will be constant. $^{2}$

In order to reproduce the pain associated with anterior cutaneous nerve entrapment, Carnett's sign is described. ${ }^{37}$ The role of this sign is to differentiate somatic from visceral abdominal pain. To perform the Carnett's test, the patient is asked to lie down and point to the specific area of abdominal pain. The examiner presses with one finger on the point of maximal tenderness as the patient raises both legs or raises the head. If the pain worsens, Carnett's sign is positive.

There are certain red flag items that are highly predictive for the diagnosis of inflammatory bowel disease (IBD). Danese et al performed a systemic literature review of 201 patients and identified eight features highly suggestive of IBD. These items include chronic abdominal pain, no postprandial abdominal pain, weight loss and fever. ${ }^{8}$

Chrona et al describe the different management strategies for ACNES. ${ }^{9}$ A literature review suggests that systemic therapies likes anti-inflammatories, weak opioids, antiepileptics and antidepressants are not effective in managing ACNES because the cause of pain is mechanical. Instead trigger point injections and ultrasound guided nerve blocks are more effective in treating ACNES. Applegate et al describe injecting a local anaesthetic with or without a corticosteroid at the point of maximal tenderness into the aponeurosis of the rectus abdominis. ${ }^{4}$ Using ultrasound guidance increases the accuracy of the nerve block and decreases the risk of entering the peritoneal cavity. For patients with recurrent pain despite nerve blocks, the use of chemical neurolysis and surgical anterior neurectomy is offered. McGrady and Marks performed chemical neurolysis using aqueous 6\% phenol in 44 patients with ACNES. ${ }^{10} 42$ patients reported significant pain relief. Anterior neurectomy involves removing the entrapped nerves surgically. Boelens et al report that 94 out of the 139 patients diagnosed with ACNES and managed with an anterior neurectomy received long-term pain relief. ${ }^{11}$

Management and treatment of ACNES can be effective with infiltration of a local anaesthetic; however, this procedure should only be performed if a cutaneous nerve entrapment is strongly suspected. Only a small percentage of patients with an unknown cause of abdominal pain presenting to the emergency department will have ACNES. ${ }^{1}$

This case reminds clinicians of the importance of careful history taking and examination, and awareness of the diagnosis of ACNES, including in patients that may have alternative causes for abdominal pain.

\section{Learning points}

Anterior cutaneous nerve entrapment syndrome (ACNES) should not be a disregarded as potential differential diagnosis in patients with Crohn's disease.

- A normal diagnostic laparoscopy has value in investigating the cause of abdominal pain in patients with Crohn's disease when the cause is not clear.

- Carnett's test is useful in differentiating between somatic and visceral abdominal pain.

- A rectus sheath nerve block under ultrasound guidance is both diagnostic and therapeutic for ACNES.

Contributors KL was involved in the write-up of this case. Data collection for this paper was led by CV, who initiated the pathology and imaging for this patient. CV was also the primary surgeon for the diagnostic laparoscopy described in the case. The analysis and interpretation of the data was completed by CV and the colorectal team. Data collected for the paper was primarily interpreted by CV. The follow-up was completed by $\mathrm{KL}$.

Funding The authors have not declared any specific grant for this research from any funding agency in the public, commercial or not-for-profit sectors.

Competing interests None declared.

Patient consent Obtained.

Ethics approval Human Reasearch Ethics Committee (HREC/17/QGC/369).

Provenance and peer review Not commissioned; externally peer reviewed.

Open access This is an open access article distributed in accordance with the Creative Commons Attribution Non Commercial (CC BY-NC 4.0) license, which permits others to distribute, remix, adapt, build upon this work non-commercially, and license their derivative works on different terms, provided the original work is properly cited and the use is non-commercial. See: http://creativecommons.org/ licenses/by-nc/4.0/

\section{REFERENCES}

1 van Assen T, Brouns JA, Scheltinga MR, et al. Incidence of abdominal pain due to the anterior cutaneous nerve entrapment syndrome in an emergency department. Scand J Trauma Resusc Emerg Med 2015;23:19. 
2 Lindsetmo RO, Stulberg J. Chronic abdominal wall pain--a diagnostic challenge for the surgeon. Am J Surg 2009;198:129-34.

3 Koop H, Koprdova S, Schürmann C. Chronic abdominal wall pain. Dtsch Arztebl Int 2016;113:51-7.

4 Applegate W. Abdominal cutaneous nerve entrapment syndrome (ACNES): a commonly overlooked cause of abdominal pain. Perm I 2002;6:20-7.

5 Costanza CD, Longstreth GF, Liu AL. Chronic abdominal wall pain: clinical features, health care costs, and long-term outcome. Clin Gastroenterol Hepatol 2004;2:395-9.

6 Applegate WV, Buckwalter NR. Microanatomy of the structures contributing to abdominal cutaneous nerve entrapment syndrome. J Am Board Fam Pract 1997;10:329-32.
7 Tanizaki R, Takemura Y. Anterior cutaneous nerve entrapment syndrome with pain present only during Carnett's sign testing: a case report. BMC Res Notes 2017;10:503.

8 Danese S, Fiorino G, Mary JY, et al. Development of red flags index for early referral of adults with symptoms and signs suggestive of Crohn's disease: an IOIBD Initiative. J Crohns Colitis 2015;9:601-6.

9 Chrona E, Kostopanagiotou G, Damigos D, et al. Anterior cutaneous nerve entrapment syndrome: management challenges. J Pain Res 2017;10:145-56.

10 McGrady EM, Marks RL. Treatment of abdominal nerve entrapment syndrome using a nerve stimulator. Ann R Coll Surg Engl 1988;70:120-2.

11 Boelens OB, Scheltinga MR, Houterman S, et al. Management of anterior cutaneous nerve entrapment syndrome in a cohort of 139 patients. Ann Surg 2011;254:1054-8.

Copyright 2019 BMJ Publishing Group. All rights reserved. For permission to reuse any of this content visit https://www.bmj.com/company/products-services/rights-and-licensing/permissions/

BMJ Case Report Fellows may re-use this article for personal use and teaching without any further permission.

Become a Fellow of BMJ Case Reports today and you can:

- Submit as many cases as you like

- Enjoy fast sympathetic peer review and rapid publication of accepted articles

- Access all the published articles

- Re-use any of the published material for personal use and teaching without further permission

\section{Customer Service}

If you have any further queries about your subscription, please contact our customer services team on +44 (0) 2071111105 or via email at support@bmj.com.

Visit casereports.bmj.com for more articles like this and to become a Fellow 